Article

\title{
Competitiveness Evaluation Methodology for Aviation Industry Sustainability Using Network DEA
}

\author{
Ki Han Song (), Solsaem Choi (1) and Ik Hyun Han *
}

Korea Transport Institute, Sejong-si 30147, Korea; kihansong@koti.re.kr (K.H.S.); thftoa9@koti.re.kr (S.C.)

* Correspondence: ih3854@koti.re.kr; Tel.: +82-044-221-3227

Received: 29 October 2020; Accepted: 2 December 2020; Published: 10 December 2020

\begin{abstract}
The purpose of this study is to develop the methodology to assess the sustainability of the aviation industry based on network data envelopment analysis (DEA) for the assessment of the national aviation industry process productivity. The national aviation industry is classified into the front stage, corresponding to the aviation market, and the behind stage, the ecosystem of the aviation industry from which added value is created. DEA for each stage and network DEA analysis from a system perspective and a process perspective were applied by integrating the two stages. Unlike the results of national productivity assessments based on previous aviation performance, it was found that the productivity varied among countries in each stage, and that the process of creating added value had the most profound effect on the overall sustainability determination of the national aviation industry. This methodology and the results are expected to contribute toward establishing the national policy direction for aviation industry sustainability.
\end{abstract}

Keywords: aviation industry sustainability; network DEA; sustainability evaluation; aviation policy; process efficiency evaluation

\section{Introduction}

The purpose of this study is to develop the methodology to assess the sustainability of the aviation industry based on network data envelopment analysis (DEA) for the assessment of national aviation industry efficiency. The methodology, which could be applied to make the national policy direction or strategy to improve both passengers and freights transportation performance and added-value creation productivity from the national economic perspective, was suggested. The state builds various systems and infrastructure for air transportation, based on which jobs and added value are created [1]. Therefore, the sustainability assessment of the air transportation ecosystem requires sustainability assessment of the aviation industry for the nation as a whole, not for individual airlines or airports.

The global aviation market prior to the COVID-19 pandemic had continued to grow and generate profits since 2010, and revenue obtained since 2015 exceeded the average cost of capital [2]. However, with the COVID-19 pandemic in 2020, commercial aviation is faced with its toughest crisis in history, and airlines and airports are bringing about change to the overall air travel experience [3]. In the midst of such drastic transformation, as the government plays an important role in responding to the change, the development of methodology to assess the sustainability of the aviation industry is more important than ever. For example, the government played a role in driving change in the aviation market with policies such as Open Skies(Agreements between governments to allow airlines to operate more freely in each other's countries) in the past and increasing air passenger traffic and networks among countries [4].

In the aviation market among countries, national competitiveness is created by comparative advantage. Accordingly, the efficiency for assessing national competitiveness should be analyzed from a relative perspective, and thus DEA is an appropriate methodology. Examples include studies 
which have analyzed the national industrial competitiveness [5,6]. Many studies have assessed the efficiency and competitiveness of airlines and airports in terms of the air transportation industry [7-11], but no studies have been found that assessed the comparative advantage of national efficiency from sustainability perspective.

In order to assess the sustainability of the national aviation market in consideration of efficiency, an efficiency analysis that reflects a series of factors from input to performance of the aviation industry as well as the resultant value-added creation is required. We set initial input factors as four factors (factor condition, demand factor, related industry, and firm structure) following Michael Porter's suggestion [12] from the national resource perspective, and intermediate factors were assumed to be produced in the aviation market. The aviation market involves national policies and numerous stakeholders, including airlines and airport operators in response. The efficiency created in this process will correspond to the overall sustainability of the entire country, and without considering this factor, it will be difficult to identify the mechanism of the national sustainability. In this study, the network DEA (NDEA) that constitutes the intermediate-level sub-DMU (decision-making unit) was applied to analyze the detailed composition at the sub-level during the process of national sustainability analysis.

For analysis of the comparative advantage of the sustainability of the aviation industry among countries, Section 2 of this study examines the adequacy of the cross-border approach of the comparative advantage and the NDEA methodology. Section 3 presents the methodology and model formulation for the application of the NDEA, such as the DMU configuration, while Section 4 analyzes the deduced results of the sustainability evaluation among countries. Section 5 describes the conclusions, including the implications.

\section{Literature Review}

Although national competitiveness for a particular industry may have various approaches, it could begin with the absolute advantage and the comparative advantage in the international trade theory. Adam Smith [13] said that if a country's enterprise has abundant factors of production or workers with special skills, it can always produce products more efficiently than those countries that do not have those factors or workers. David Ricardo [14] argued that a country can still trade insofar as it has a product with a comparative advantage even if it does not have an absolute advantage in producing a certain product, which demonstrates that a country allocates its resources to industries with relatively higher productivity. Although the definitions vary slightly from one another, the most important notion is "advantage," focusing on whether one country outpaces another in terms of cross-border competition or advantage.

It was Michael Porter [14] who shifted the paradigm of traditional economic theory, which lasted for over 200 years, and he argued that competitiveness depends on the capability held by the industries in the country, not on the advantages based on resources, workforce, and monetary value that the conventional economic theory had claimed. His diamond model presented a direction developed further from the traditional trade theory, but it also had limitations as it failed to reflect comprehensive factors such as internationalization, and therefore, models expanding competitiveness continued to be released.

Cho, D.S. [15] expanded the variables that Porter had presented to include physical and human factors (workers, politicians and administrative officials, entrepreneurs, and experts) as the roles of the government and entrepreneurs were important in developing countries like Korea. Moon et al. [16] expanded parts, such as internalization, that Porter's diamond model failed to address into the double diamond model. Cho, Moon, and Kim [17] presented the IPS (Institute of Industrial Policy Studies) model that analyzes physical and human factors with a single framework at domestic and international levels, including the earlier expansion into physical and human factors and the internationalization factor. Data envelopment analysis (DEA) may be useful to derive "competitive advantage", which is an important notion in such strategic analysis frameworks. 
Data envelopment analysis (DEA) led to the creation of the DEA model based on linear programming through a study by Charnes, Cooper, and Rhodes [18]. Banker, Charnes, and Cooper [19] later presented the model of variable returns to scale by mitigating the conditions of the variable returns to scale. Since then, DEA has been used in various fields as it expresses the relative efficiency of decision-making units (DMUs) with multiple inputs and outputs in a single index [20].

Melecký, L. and Staníčková, M. [6] performed the national efficiency evaluation through DEA analysis. In the study, the concept of competitiveness was defined as an evaluation by the decomposition of aggregate macroeconomic indicators, and it used data at the national level to analyze national competitiveness. Martín, J. C., Mendoza, C., and Román, C. [10] ranked 139 countries by creating composite indicators for travel-tourism competitiveness through DEA analysis based on national data.

Thus far, most studies using DEA in the aviation sector have been carried out by analyzing the efficiency of companies such as airlines and airports. Good, D. H., Röller, L. H., and Sickles, R. C. [9] compared the competitiveness of European and US airlines based on labor costs, fuel costs, non-flight assets, and aircraft as input factors and the total revenue as an output factor, and concluded that 4 billion US dollars could be saved yearly if EU airlines were as efficient as US airlines in terms of productivity. Merkert, R. and Hensher, D. A. [11] analyzed the strategic management of 58 airlines and the efficiency according to aircraft plans based on a two-stage DEA. In this study, aircraft size and aircraft fleet combination had the greatest impact on the cost efficiency of airlines, and aircraft year had a positive effect on aircraft allocative and cost efficiency, even though it did not have a significant effect on the technical efficiency.

Gillen, D. and Lall, A. [8] measured the productivity for terminals and airside operations over a period of five years for 21 airports in the United States and analyzed the impact of various airport variables on efficiency, such as hub airport status, noise strategy, number of boarding gates, and number of runways, through Tobit regression analysis. They suggested that general aviation traffic reduction and gate capacity expansion are important main factors to improve efficiency. Martín, J. C. and Roman, C. [5] analyzed the technological efficiency of inputs (labor, capital, and materials) at 37 Spanish airports through DEA for air traffic movements, passengers, and cargo, and found that the revenue ratio to airport size increased as the size in 20 airports while not in 9 airports. Barros and Dieke (2007) [7] showed the efficiency of 31 Italian airports through DEA using three years of panel data from 2001 to 2003 to suggest a benchmark reference for low performance airports, and it was found that large airport authorities are more efficient than small airport authorities and airports under fully private management are more efficient than those under partially private management.

In the aviation sector, a number of studies have been conducted using DEA to analyze the efficiency of airlines and airports. However, we could not find previous studies that evaluated the sustainability of the overall aviation industry based on national competitiveness and added-value productivity. The airline and airport research that has been conducted thus far had limitations in reflecting multiple DMU interrelationships to link them to aviation industry sustainability. There has been a NDEA study to address efficiency level at each stage. In this study, NDEA is applied to determine the sustainability of the national aviation industry based on the comparative advantage concept.

\section{Methodology}

We assumed the national air transportation market as a virtual DMU and made a premise that it is comprised of two stages: the demand and supply balancing stage (front stage) in the market and the value creation stage (behind stage) in the ecosystem of the air transportation industry. The aviation transport industry was assumed to be the main industry, and related industries [21] were included to evaluate the sustainability of added-value creation. Although there are many studies that have taken an approach of setting airports or airlines as DMU, we proposed a sustainability measurement method for the national aviation market and eco-system. In addition, the Wilcoxon rank-sum test was conducted for the sustainability indicator results to test the difference in the average for the front stage, the behind stage, and the entire process within the model, and Pearson correlation analysis was 
employed to conduct a similarity analysis for each stage by model. In addition, we conducted cluster analysis (K-means clustering) to examine how the characteristics of national aviation industries by country were classified.

As for the methodology of the each stage or the two-stage combined productivity measurement, each stage evaluation model with CRS (constant returns to scale) assumption (hereinafter, "IM"), ratio-form system productivity evaluation model (hereinafter, "RSM"), and ratio-form process productivity evaluation model (hereinafter, "RPM") among the models presented by Chiang Kao [22] were compared and applied. By comparing and analyzing the three methodologies, the meaning that the front stage and the behind stage efficiency have in the national aviation market was interpreted in terms of overall sustainability. The remaining models except IM assume the basic two-stage structure, and RPM was analyzed by dividing the two cases of intermediate measures with the same weights and with different weights.

The national aviation market input was assumed to be four factors corresponding to factor condition, demand factor, related industry, and firm structure, as presented in Michael Porter's diamond theory [14]. The input corresponding to the factor condition was assumed to be the capital for the aviation industry held by the state and set as the number of routes and airports. The demand factor presumed the purchasing power parity (PPP)-based GDP and population in consideration of sectors because aviation demand is derived from socio-economic activities. In terms of the related industry, tourist attractions were set to reflect the association of tourism from the related demand perspective, with the firm structure as the inverse Herfindahl-Hirschman index (HHI) for airlines.

The final output provided by the state was assumed to be value-added creation from the national economic perspective (Figure 1). RPK (revenue-passenger-kilometer), CTK (cargo-ton-kilometer), and $\mathrm{HHI}$ were calculated as intermediate products at the front stage. HHI is an index for the degree of dispersion by route, and it would be considered an input for which the national industry creates added value in the next step of the behind stage. At the behind stage, the output was set to create added value.

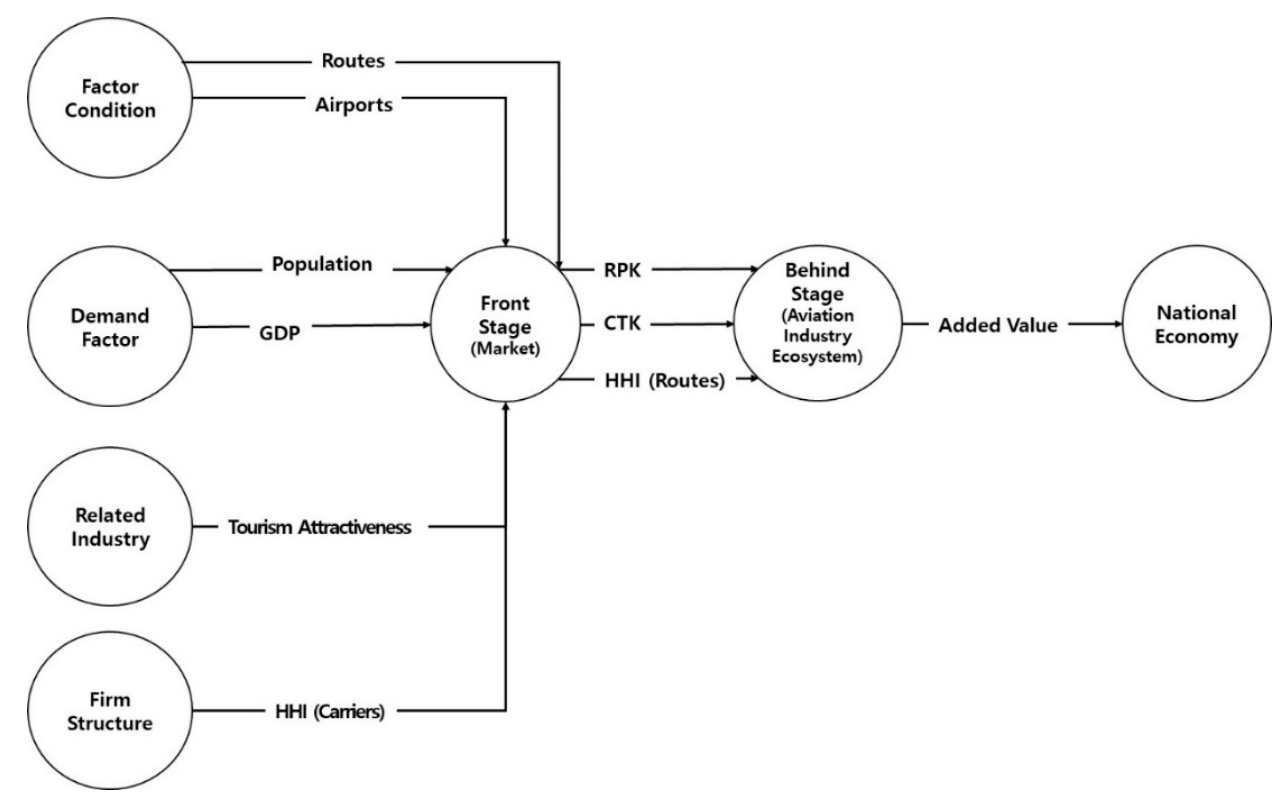

Figure 1. Concept of national aviation industry network. Abbreviations: RPK, revenue-passenger-km; CTK, cargo-ton-km; HHI, Herfindahl-Hirschman index.

Using network DEA, we derived the productivity in the front stage $E_{n}^{m}$, productivity in the behind stage $E_{n}^{a}$, and overall aviation industry sustainability $E_{n}^{t}$ that the country $\mathrm{n}$ has. Here, input for country $\mathrm{n}$ was set as the number of routes $I_{1 n}$, number of airports $I_{2 n}$, GDP $I_{3 n}$, population $I_{4 n}$, tourist attractions $I_{5 n}$, and inverse HHI $I_{6 n}$, while the final outcome was set as the total added value $O_{1 n}$. As for the 
intermediate products of the country, RPK, CTK, and HHI were set as $C_{1 n}, C_{2 n}$, and $C_{3 n}$, respectively. Hereafter, $f y$ is defined as the total number of input categories, $h y$ as the intermediate products, and $g y$ as the number output categories. The final formulation of each methodology is shown in Table 1.

Table 1. Model program. Note: IM, constant returns to scale assumption; RSM, ratio-form system productivity evaluation model; RPM, ratio-form process productivity evaluation model.

\begin{tabular}{|c|c|c|}
\hline \multicolumn{2}{|c|}{ Model } & Equation \\
\hline \multirow[t]{2}{*}{ IM_Front } & Program & $\begin{array}{l}E_{n}^{m}=\max \frac{\sum_{h=1}^{h y} Q_{h} C_{h n}}{\sum_{f=1}^{f y} P_{f} I_{f n}} \\
\text { s.t. } \frac{\sum_{h=1}^{h y} Q_{h} C_{h n}}{\sum_{f=1}^{f y} P_{f} I_{f n}} \leq 1, \forall n \\
P_{f}, Q_{h} \geq \varepsilon\end{array}$ \\
\hline & Productivity & $E_{n}^{m}=\frac{\sum_{h=1}^{h y} Q_{h}^{*} C_{h n}}{\sum_{f=1}^{f y} P_{f}^{*} I_{f n}}$ \\
\hline \multirow[t]{2}{*}{ IM_Behind } & Program & $\begin{array}{l}E_{n}^{a}=\max \frac{\sum_{g=1}^{g y} R_{g} O_{g n}}{\sum_{h=1}^{h y} S_{h} C_{h n}} \\
\text { s.t. } \frac{\sum_{g=1}^{g y} R_{g} O_{g n}}{\sum_{h y=1}^{h y} S_{h} C_{h n}} \leq 1, \forall n \\
S_{h}, R_{g} \geq \varepsilon\end{array}$ \\
\hline & Productivity & $E_{n}^{a}=\frac{\sum_{g=1}^{g y} R_{g}^{*} O_{g^{n}}}{\sum_{h=1}^{h y} S_{h}^{*} C_{h n}}$ \\
\hline \multirow{2}{*}{ RSM } & Program & $\begin{array}{l}E_{n}^{t}=\max \frac{\sum_{g=1}^{g y} R_{g} O_{g n}}{\sum_{f=1}^{f y} P_{f} I_{f n}} \\
\text { s.t. } \frac{\sum_{h=1}^{h y} Q_{h} C_{h n}}{\sum_{f=1}^{f y} P_{f} I_{f n}} \leq 1, \forall n \\
\frac{\sum_{g=1}^{g y} R_{g} O_{g n}}{\sum_{h=1}^{h y} Q_{h} C_{h n}} \leq 1, \forall n \\
P_{f}, Q_{h}, R_{g} \geq \varepsilon\end{array}$ \\
\hline & Productivity & $\begin{array}{l}E_{n}^{t}=\frac{\sum_{g=1}^{g y} R_{g}^{*} O_{g n}}{\sum_{f=1}^{f y} P_{f}^{*} I_{f n}} \\
E_{n}^{m}=\frac{\sum_{h=1}^{h y} Q_{h}^{*} C_{h n}}{\sum_{f=1}^{f y} P_{f}^{*} I_{f n}} \\
E_{n}^{a}=\frac{\sum_{g=1}^{g y} R_{g}^{*} O_{g n}}{\sum_{h=1}^{h y} Q_{h}^{*} C_{h n}}\end{array}$ \\
\hline \multirow[t]{2}{*}{ RPM_Same Weights } & Program & $\begin{array}{l}E_{n}^{t}=\max \frac{\sum_{h=1}^{h y} Q_{h} C_{h n}+\sum_{g=1}^{g y} R_{g} O_{g n}}{\sum_{f=1}^{f y} P_{f} I_{f n}+\sum_{h=1}^{h y} S_{h} C_{h n}} \\
\text { s.t. } \frac{\sum_{h=1}^{h y} Q_{h} C_{h n}}{\sum_{f=1}^{f y} P_{f} I_{f n}} \leq 1, \forall n \\
\frac{\sum_{g=1}^{g y} R_{g} O_{g n}}{\sum_{h=1}^{h y} S_{h} C_{h n}} \leq 1, \forall n \\
P_{f}, Q_{h}, R_{g} \geq \varepsilon\end{array}$ \\
\hline & Productivity & $\begin{array}{l}E_{n}^{t}=\frac{\sum_{h=1}^{h y} Q_{h}^{*} C_{h n}+\sum_{g=1}^{g y} R_{g}^{*} O_{g n}}{\sum_{f=1}^{f y} P_{f}^{*} I_{f n}+\sum_{h=1}^{h y} S_{h}^{*} C_{h n}} \\
E_{n}^{m}=\frac{\sum_{h=1}^{h y} Q_{h}^{*} C_{h n}}{\sum_{f=1}^{f y} P_{f}^{*} I_{f n}} \\
E_{n}^{a}=\frac{\sum_{g=1}^{g y} R_{g}^{*} O_{g n}}{\sum_{h=1}^{h y} S_{h}^{*} C_{h n}}\end{array}$ \\
\hline \multirow[t]{2}{*}{ RPM_Different Weights } & Program & $\begin{array}{l}E_{n}^{t}=\max \frac{\sum_{h=1}^{h y} Q_{h} C_{h n}+\sum_{g=1}^{g y} R_{g} O_{g n}}{\sum_{f=1}^{f y} P_{f} I_{f n}+\sum_{h=1}^{h y} S_{h} C_{h n}} \\
\text { s.t. } \frac{\sum_{h=1}^{h y} Q_{h} C_{h n}}{\sum_{f=1}^{f y} P_{f} I_{f n}} \leq 1, \forall n \\
\frac{\sum_{g=1}^{g y} R_{g} O_{g^{n}}}{\sum_{h=1}^{h y} S_{h} C_{h n}} \leq 1, \forall n \\
\sum_{h=1}^{h y} Q_{h} C_{h n} \leq \sum_{h=1}^{h y} S_{h} C_{h n}, \forall n \\
P_{f}, S_{h}, Q_{h}, R_{g} \geq \varepsilon\end{array}$ \\
\hline & Productivity & $\begin{array}{l}E_{n}^{t}=\frac{\sum_{h=1}^{h y} Q_{h}^{*} C_{h n}+\sum_{g=1}^{g y} R_{g}^{*} O_{g n}}{\sum_{f=1}^{f y} P_{f}^{*} I_{f n}+\sum_{h=1}^{h y} S_{h}^{s} C_{h n}} \\
E_{n}^{m}=\frac{\sum_{h=1}^{h y} Q_{h}^{*} C_{h n}}{\sum_{f=1}^{f y} P_{f}^{*} I_{f n}} \\
E_{n}^{a}=\frac{\sum_{g=1}^{g y} R_{g}^{*} O_{g n}}{\sum_{h=1}^{h y} S_{h}^{*} C_{h n}}\end{array}$ \\
\hline
\end{tabular}




\section{Results}

The base year was set to 2017 where the data were obtainable, and the sustainability indices of the air transportation industry were derived for 56 countries, while the definitions of input factors for the evaluation indices were as shown in Table 2. For each factor, the number of routes was set as the number of routes between airports by country (including both international and domestic flights), the number of airports was the number of airports in the base year by country, the population was the population in the base year by country, and the GDP was the gross domestic product reflecting the purchase power parity in the base year. The tourist attraction index was defined as the travel and tourism competitiveness index, RPK and CTK as the revenue per kilometers and freight ton-kilometers in the respective year, the amount of added value as the aviation added value aggregated by the Air Transport Action Group, and the inverse Herfindahl-Hirschman Index(HHI) by setting the market concentration by country as the inverse ratio (see Appendix A for further details).

Table 2. Definition of network-data envelopment analysis (DEA) factors. PPP, purchase power parity.

\begin{tabular}{|c|c|c|c|}
\hline Type & Factor & Unit & Definition \\
\hline \multirow{6}{*}{ Inputs } & Number of routes & - & $\begin{array}{l}\text { Number of routes between } \\
\text { airports by country } \\
\text { (international + domestic) }\end{array}$ \\
\hline & Number of airports & - & Number of airports by country \\
\hline & Population & Thousand & Population by country \\
\hline & GDP & USD 100 million & PPP-based GDP by country \\
\hline & Tourist attraction & - & $\begin{array}{c}\text { Travel and tourism } \\
\text { competitiveness index } \\
\text { (World Economic Forum) }\end{array}$ \\
\hline & $\begin{array}{l}\text { Inverse HHI index } \\
\text { (airline) }\end{array}$ & - & $\begin{array}{l}\text { Inverse market concentration of } \\
\text { airlines by country }\end{array}$ \\
\hline \multirow{3}{*}{ Intermediates } & RPK & - & Revenue per kilometers \\
\hline & CTK & - & Cargo tonne-kilometers \\
\hline & $\begin{array}{l}\text { Inverse } \mathrm{HHI} \text { index } \\
\text { (route) }\end{array}$ & - & $\begin{array}{l}\text { Inverse market concentration of } \\
\text { routes by country }\end{array}$ \\
\hline Outputs & Amount of added value & - & $\begin{array}{l}\text { Aggregate aviation added value } \\
\text { (Air Transport Action Group) }\end{array}$ \\
\hline
\end{tabular}

Each IM regarding both the front stage efficiency and the behind stage efficiency produced higher productivity than the other models. As for RSM, the average of the results (front stage efficiency and overall efficiency) excluding the behind stage efficiency appears to be lower than those of the other models. For RPM, there was little difference in the deduction between models with different weights and the model with the same weight (see Table 3 for further details). For each IM, the countries at the top in terms of front stage efficiency were analyzed to be China, Hong Kong, Ethiopia, Finland, Iceland, Ireland, Israel, Latvia, Lebanon, Luxembourg, Malta, Nigeria, Panama, Rwanda, Singapore, South Africa, Turkey, the United Arab Emirates (UAE), and the United States. GDP, population, and routes number in those countries are summed up to about from $39 \%$ to $41 \%$ compared to total sum of investigated countries. The countries at the top in the behind stage efficiency were found to be the United States, Greece, Italy, Mexico, and Spain. As for the behind stage, North America and Europe were found to be ranked high. Added-value sum of those five countries was around $43 \%$ of investigated countries total, and United States, Mexico, and Spain have a long aviation history such that Mexicana Airlines and American Airlines were founded in 1921, and Iberia Airline in 1928. (See Appendices B and C for further result details). 
Table 3. Average of evaluation.

\begin{tabular}{cccc}
\hline Category & $\begin{array}{c}\text { Front-Stage } \\
\text { Productivity }\end{array}$ & $\begin{array}{c}\text { Behind-Stage } \\
\text { Productivity }\end{array}$ & $\begin{array}{c}\text { Total } \\
\text { Productivity }\end{array}$ \\
\hline IM-Model & 0.9064 & 0.3886 & - \\
RSM-Model & 0.5274 & 0.2720 & 0.1404 \\
RPM-Model & 0.8702 & 0.1508 & 0.5226 \\
$\begin{array}{c}\text { (Same weight) } \\
\text { RPM-Model }\end{array}$ & 0.8710 & 0.1507 & 0.5228 \\
\hline
\end{tabular}

In the case of RSM, countries in North America, Europe, and East Asia, including China, Hong Kong, Iceland, Ireland, Singapore, the UAE, and the United States, took the top slots with the highest front stage productivity indices. As for behind stage productivity, the United States, Spain, Mexico, Japan, and France were found to be the top five countries, with countries in North America, Europe, and East Asia taking the top spot in a similar manner to the front stage, while the United States, Spain, the United Kingdom, Japan, and France were derived as the top five countries in overall productivity. The RPM results were analyzed to have similar results to IM in terms of the front stage productivity and to RSM in terms of the behind stage productivity as well as the total productivity (See Appendices B-E for further details).

By comparing each stage productivity results of the applied model through the Wilcoxon rank sum test (similar results were derived for the same weight and different weights of the RPM-model), the front stage, the behind stage, and the overall productivity results could not be regarded to have the same pattern (Table 4). This means that certain stages cannot be considered to determine the overall productivity results, indicating the need to apply network DEA in the sustainability analysis of the national aviation industry.

Table 4. Results of the Wilcoxon rank sum test.

\begin{tabular}{ccc}
\hline Model & $\boldsymbol{H}_{0}$ & $\boldsymbol{p}$-Value \\
\hline \multirow{2}{*}{ RPM } & $E_{n}^{m}=E_{n}^{a}$ & $<2.2 \times 10^{-16}$ \\
(With different weight) & $E_{n}^{m}=E_{n}^{t}$ & $3.141 \times 10^{-14}$ \\
& $E_{n}^{a}=E_{n}^{t}$ & $8.08 \times 10^{-14}$ \\
\hline \multirow{2}{*}{ RSM } & $E_{n}^{m}=E_{n}^{a}$ & $1.362 \times 10^{-8}$ \\
& $E_{n}^{m}=E_{n}^{t}$ & $<2.2 \times 10^{-16}$ \\
& $E_{n}^{a}=E_{n}^{t}$ & 0.000571 \\
\hline
\end{tabular}

Table 5 shows the results that compare the difference between models through the Pearson correlation coefficient test (as a result of comparing the same weight and different weights of RPM, the correlation coefficient was derived to be almost 1 , and thus it was excluded). The overall productivity correlation coefficient of RPM and RSM was derived to be the highest, while the correlation coefficient of the front stage efficiency in the same results was derived to be lowest. Based on the characteristics of each model, IM and RPM were derived to have high correlation coefficient in the front stage, whereas RSM had high correlation coefficient in the behind model. In terms of system sustainability, a strong similarity was found in the behind stage, while the similarity in the front stage was evident in terms of the process sustainability. 
Table 5. Results of Pearson correlation coefficient test by model. DW, with different weight.

\begin{tabular}{ccccc}
\hline \multirow{2}{*}{ Category } & \multicolumn{2}{c}{ Pearson Correlation Coefficient } \\
\cline { 3 - 5 } & RPM-Model (DW) & $\begin{array}{c}\text { Front-Stage } \\
\text { Productivity }\end{array}$ & $\begin{array}{c}\text { Behind-Stage } \\
\text { Productivity }\end{array}$ & Total Productivity \\
\hline IM-Model & RSM-Model & 0.8369 & 0.5952 & - \\
IM-Model & RSM-Model & 0.3903 & 0.8188 & - \\
RPM-Model (DW) & RM & 0.8318 & 0.8680 \\
\hline
\end{tabular}

We conducted K-means cluster analysis for the results of RPM and RSM (Figures 2 and 3). Using the sum of squares in the cluster, the optimal number of clusters for each model was estimated (see Figure 2 for further details). Three for RSM and two for RPM were derived to be the optimal number of groups. In RSM and RPM, the groups were divided into those with high and low behind stage efficiencies and those with high and low front stage productivity. In RSM, the groups were found to be divided into those with high and low behind stages, indicating that the behind stage serves as a standard for classifying major groups.
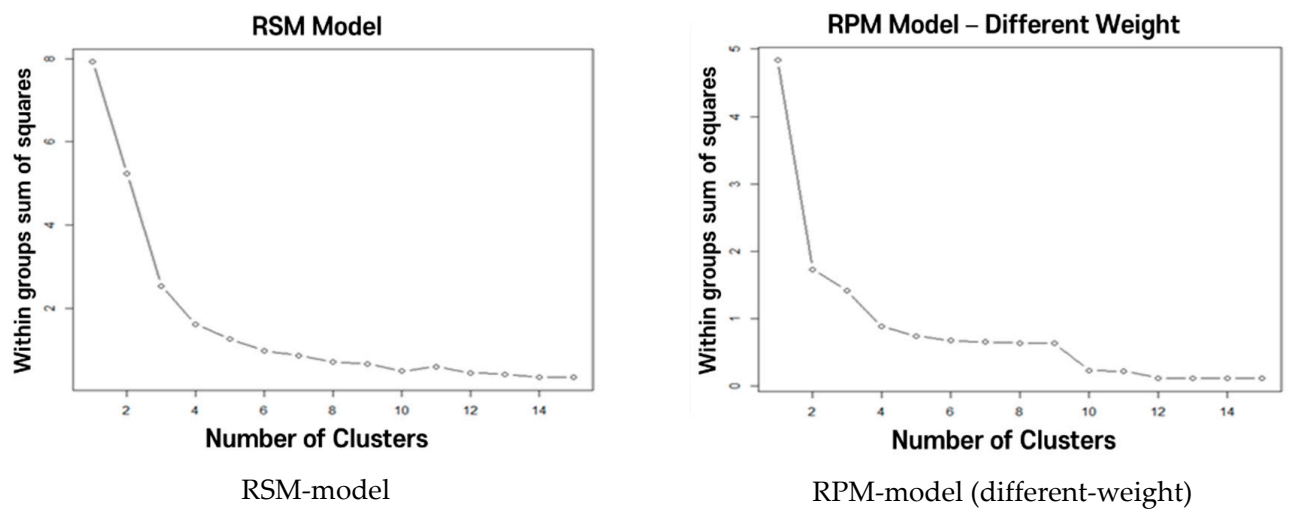

Figure 2. K-means test for an appropriate number of clusters.

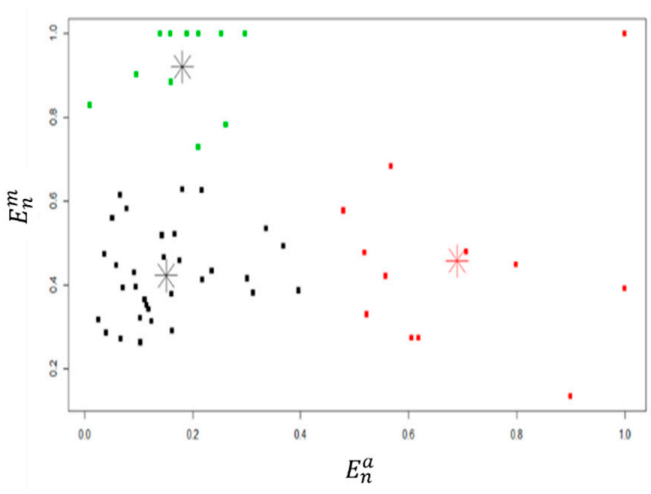

RSM-model

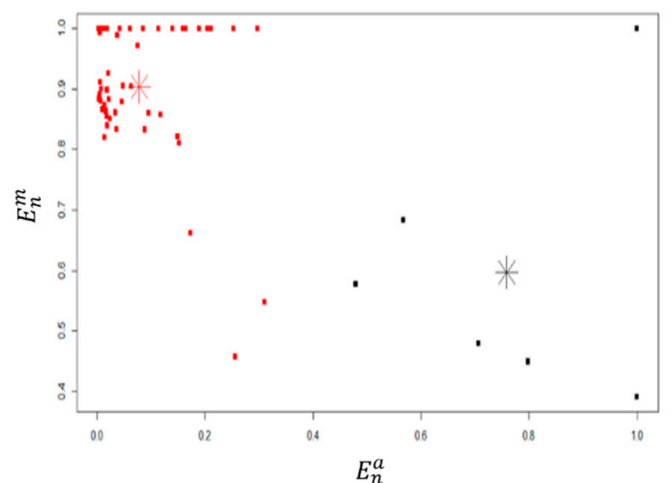

RPM-model (different-weight)

Figure 3. Results of K-means cluster analysis.

\section{Conclusions}

The strategic concept of sustainable national competitiveness was applied as an attempt to analyze the sustainability based on productivity competitiveness of the aviation industry. Productivity in this paper was assumed to be based on added-value output from the national aviation industry ecosystem compared to initial and intermediate inputs. Previous studies that have focused on individual airlines and airports were expanded to cover the scope of the national aviation industry to define the sustainability of the aviation industry in terms of productivity and the comparative advantage of each country. Although the concept of competitiveness could be viewed as relative and complex, 
the analysis of the existing national aviation industry determined the competitiveness ranking with primary indices such as the ratio based on performance [23]. To overcome this issue focused only on efficiency based on simple output to input ratio, we analyzed the national aviation industry productivity and global competitiveness of the cross-border aviation industry by utilizing the Porter's concept of national competitiveness [14] and network DEA from an aviation industry sustainability perspective. For example, Korea's air transportation performance in terms of passengers and freights carried is ranked 6th in the world (as of 2018), but we showed that the country was ranked 23rd in the IM-model efficiency evaluation standard and 27th in the RPM-model (different weight) standard, which had previously been difficult to quantify.

In the concept of sustainability, we suggested that productivity analysis could provide direction for national sustainability policies. For example, if behind stage productivity is much lower compared to front stage performance, the policy focused on the industry scale increase could be changed to the sustainability improvement policy of national aviation industry from the added-value enhancement perspective. Each national aviation policy plan presents the index ratio in the aviation sector [24,25] as a competitive index, but there were structural limitations in the approach of competitiveness analysis such as the business development stage classified into "factor-driven", "investment-driven", "innovation-driven", and "wealth-driven" as presented by Porter [14]. In this study, the results that enable the analysis of national competitiveness from the sustainability perspective of national aviation industry systems and added value-making processes through network DEA were presented. We showed that the productivity demonstrated in the market and the creation of added value in the national economy could be included to evaluate the sustainability of the overall aviation industry.

Furthermore, we expect for our analysis to be useful as basic data for the policies of the national aviation industry sustainability. For example, Korea shows high productivity in the front stage, which means the market, but in the behind stage, which means creating added value, shows low productivity, thereby reducing the overall productivity. This means that it is necessary to set the policy direction towards creating qualitative added value along with the quantitative expansion of aviation demand such as a LCC (low cost carrier) support policy and so on.

From the perspective of the global aviation industry, the cross-border group was formed based on the characteristics of the cross-border aviation industry. In this process, from an air transportation perspective, groups across countries confirmed that the level of value-added creation could be the top priority standard for classifying groups for cross-border groups. This shows that from the perspective of the global aviation industry, the contribution towards value-added creation through the ecosystem of the aviation industry of each country, along with the competition for demand in the front stage, is also a major factor to consider.

Finally, we presented a novel methodology to analyze the sustainability of the aviation industry based on the productivity evaluation concept of the overall system and showed the result availability from the perspective of national policy. We proposed a methodology different from previous studies in introducing the national aviation industry as a decision-making unit and suggesting a two-stage analysis composed of the aviation market and the aviation industry eco-system stage, and we recommend that added-value creation also be considered from the aviation industry sustainability perspective. Moreover, further studies are needed to find the hidden mechanism of added-value creation in the aviation industry ecosystem and validate the developed methodology based on empirical studies. We also provide the starting point for continuous future studies on the aviation industry sustainability from the comparative advantage perspective and the policy direction for the aviation industry to be contributed to the national economy.

Author Contributions: Conceptualization, K.H.S. and I.H.H.; methodology, K.H.S. and S.C.; software, K.H.S. and S.C.; investigation, I.H.H. and S.C.; resources, I.H.H. and S.C.; formal analysis, K.H.S. and S.C.; data curation, I.H.H. and S.C.; writing-original draft preparation, S.C. and K.H.S.; writing-review and editing, K.H.S. and S.C.; supervision, K.H.S.; project administration K.H.S. and I.H.H. All authors have read and agreed to the published version of the manuscript. 
Funding: This study was funded by the Korea Transport Institute for its task "Research project for enhancement of airport competitiveness and regional development in Korea by the year 2020." Grant number 31-20-014 And The APC was funded by Korea Transport Institute.

Conflicts of Interest: The authors declare no conflict of interest.

Appendix A. Basic Statistics Analysis of Network DEA Factors

\begin{tabular}{cccccc}
\hline Factor (Unit) & Average & $\begin{array}{c}\text { Standard } \\
\text { Deviation }\end{array}$ & $\begin{array}{c}\text { Median } \\
\text { Value }\end{array}$ & MAX & MIN \\
\hline Number of routes & $12,467.63$ & $24,784.65$ & 5756 & 181,268 & 950 \\
Number of airports & 35.07 & 49.25 & 16.5 & 230 & 1 \\
Population & $99,646.91$ & $254,176.8$ & $32,271.72$ & $1,386,395$ & 343.40 \\
GDP & $19,029.11$ & $37,719.47$ & 6687.38 & $198,870.3$ & 190.80 \\
Tourist attraction & 4.68 & 0.38 & 4.70 & 5.40 & 3.80 \\
Inverse HHI index (airline) & 0.87 & 0.08 & 0.89 & 0.96 & 0.53 \\
RPK & $121,937.1$ & $243,302.5$ & 34,863 & $1,551,965$ & 1088 \\
CTK & $19,645.45$ & $37,644.45$ & 5810.5 & 184,130 & 109 \\
Inverse HHI index (route) & 0.90 & 0.07 & 0.92 & 0.97 & 0.56 \\
Amount of added value & 41.59 & 105.42 & 14.60 & 778.40 & 0.12 \\
\hline
\end{tabular}

Appendix B. IM Efficiency Evaluation Results. DMU, Decision-Making Unit

\begin{tabular}{|c|c|c|c|c|c|c|}
\hline \multirow[t]{2}{*}{$\begin{array}{c}\text { DMU } \\
\text { (Country) }\end{array}$} & \multicolumn{2}{|c|}{$\begin{array}{c}E_{n}^{m} \text { (Front-Stage } \\
\text { Efficiency) }\end{array}$} & \multicolumn{2}{|c|}{$\begin{array}{c}E_{n}^{a} \text { (Behind-Stage } \\
\text { Efficiency) }\end{array}$} & \multicolumn{2}{|c|}{$E_{n}^{t}$ (Total Efficiency) } \\
\hline & $\begin{array}{l}\text { Evaluation } \\
\text { Index Results }\end{array}$ & Rank & $\begin{array}{c}\text { Evaluation } \\
\text { Index Results }\end{array}$ & Rank & $\begin{array}{c}\text { Evaluation } \\
\text { Index Results }\end{array}$ & Rank \\
\hline Argentina & 0.88 & 33 & 0.34 & 25 & - & - \\
\hline Australia & 0.85 & 45 & 0.52 & 16 & - & - \\
\hline Austria & 0.87 & 36 & 0.28 & 29 & - & - \\
\hline Belgium & 0.93 & 23 & 0.39 & 21 & - & - \\
\hline Brazil & 0.86 & 42 & 0.17 & 47 & - & - \\
\hline Canada & 0.68 & 55 & 0.36 & 24 & - & - \\
\hline Chile & 0.86 & 41 & 0.18 & 44 & - & - \\
\hline China & 1.00 & 1 & 0.21 & 37 & - & - \\
\hline Hong Kong & 1.00 & 1 & 0.25 & 30 & - & - \\
\hline Colombia & 0.87 & 39 & 0.20 & 40 & - & - \\
\hline Czech Republic & 0.88 & 32 & 0.19 & 42 & - & - \\
\hline Egypt & 0.82 & 50 & 0.24 & 33 & - & - \\
\hline Ethiopia & 1.00 & 1 & 0.11 & 53 & - & - \\
\hline Finland & 1.00 & 1 & 0.16 & 48 & - & - \\
\hline France & 0.80 & 52 & 0.71 & 9 & - & - \\
\hline Germany & 0.84 & 48 & 0.48 & 17 & - & - \\
\hline Greece & 0.84 & 49 & 1.00 & 1 & - & - \\
\hline Hungary & 0.99 & 20 & 0.07 & 56 & - & - \\
\hline Iceland & 1.00 & 1 & 0.16 & 49 & - & - \\
\hline India & 0.90 & 29 & 0.25 & 31 & - & - \\
\hline Indonesia & 0.88 & 35 & 0.23 & 35 & - & - \\
\hline Ireland & 1.00 & 1 & 0.15 & 50 & - & - \\
\hline Israel & 1.00 & 1 & 0.55 & 13 & - & - \\
\hline Italy & 0.84 & 47 & 1.00 & 1 & - & - \\
\hline Japan & 0.78 & 53 & 0.80 & 6 & - & - \\
\hline Jordan & 0.88 & 34 & 0.18 & 43 & - & - \\
\hline
\end{tabular}




\begin{tabular}{|c|c|c|c|c|c|c|}
\hline \multirow[t]{2}{*}{$\begin{array}{c}\text { DMU } \\
\text { (Country) }\end{array}$} & \multicolumn{2}{|c|}{$\begin{array}{c}E_{n}^{m} \text { (Front-Stage } \\
\text { Efficiency) }\end{array}$} & \multicolumn{2}{|c|}{$\begin{array}{c}E_{n}^{a} \text { (Behind-Stage } \\
\text { Efficiency) }\end{array}$} & \multicolumn{2}{|c|}{$E_{n}^{t}$ (Total Efficiency) } \\
\hline & $\begin{array}{c}\text { Evaluation } \\
\text { Index Results }\end{array}$ & Rank & $\begin{array}{c}\text { Evaluation } \\
\text { Index Results }\end{array}$ & Rank & $\begin{array}{c}\text { Evaluation } \\
\text { Index Results }\end{array}$ & Rank \\
\hline Kenya & 0.91 & 24 & 0.21 & 38 & - & - \\
\hline Latvia & 1.00 & 1 & 0.17 & 46 & - & - \\
\hline Lebanon & 1.00 & 1 & 0.77 & 8 & - & - \\
\hline Luxembourg & 1.00 & 1 & 0.38 & 22 & - & - \\
\hline Malaysia & 0.85 & 43 & 0.10 & 54 & - & - \\
\hline Malta & 1.00 & 1 & 0.78 & 7 & - & - \\
\hline Korea & 0.87 & 37 & 0.37 & 23 & - & - \\
\hline Mexico & 0.53 & 56 & 1.00 & 1 & - & - \\
\hline Morocco & 0.84 & 46 & 0.40 & 20 & - & - \\
\hline Netherlands & 0.89 & 30 & 0.21 & 39 & - & - \\
\hline New Zealand & 0.75 & 54 & 0.55 & 14 & - & - \\
\hline Nigeria & 1.00 & 1 & 0.47 & 19 & - & - \\
\hline Panama & 1.00 & 1 & 0.23 & 36 & - & - \\
\hline Peru & 0.87 & 38 & 0.17 & 45 & - & - \\
\hline Philippines & 0.90 & 27 & 0.15 & 51 & - & - \\
\hline Poland & 0.90 & 26 & 0.24 & 34 & - & - \\
\hline Portugal & 0.85 & 44 & 0.33 & 26 & - & - \\
\hline Romania & 0.89 & 31 & 0.28 & 28 & - & - \\
\hline Russia & 0.99 & 21 & 0.14 & 52 & - & - \\
\hline Rwanda & 1.00 & 1 & 0.08 & 55 & - & - \\
\hline Saudi Arabia & 0.98 & 22 & 0.54 & 15 & - & - \\
\hline Singapore & 1.00 & 1 & 0.30 & 27 & - & - \\
\hline South Africa & 1.00 & 1 & 0.25 & 32 & - & - \\
\hline Spain & 0.82 & 51 & 1.00 & 1 & - & - \\
\hline Switzerland & 0.91 & 25 & 0.48 & 18 & - & - \\
\hline Thailand & 0.86 & 40 & 0.57 & 12 & - & - \\
\hline Turkey & 1.00 & 1 & 0.68 & 10 & - & - \\
\hline UAE & 1.00 & 1 & 0.19 & 41 & - & - \\
\hline United Kingdom & 0.90 & 28 & 0.58 & 11 & - & - \\
\hline United States & 1.00 & 1 & 1.00 & 1 & - & - \\
\hline
\end{tabular}

Appendix C. RPM: Efficiency Evaluation Results for Different Weights

\begin{tabular}{|c|c|c|c|c|c|c|}
\hline \multirow{2}{*}{$\begin{array}{c}\text { DMU } \\
\text { (Country) }\end{array}$} & \multicolumn{4}{|c|}{$\begin{array}{c}\text { Evaluation Results (Scores } \\
E_{n}^{a} \text { (Behind-Stage } \\
\text { Efficiency) }\end{array}$} & \multicolumn{2}{|c|}{$E_{n}^{t}$ (Total Efficiency) } \\
\hline & $\begin{array}{c}\text { Evaluation } \\
\text { Index Results }\end{array}$ & Rank & $\begin{array}{c}\text { Evaluation } \\
\text { Index Results }\end{array}$ & Rank & $\begin{array}{c}\text { Evaluation } \\
\text { Index Results }\end{array}$ & Rank \\
\hline Argentina & 0.88 & 31 & 0.02 & 35 & 0.48 & 39 \\
\hline Australia & 0.82 & 46 & 0.15 & 18 & 0.52 & 20 \\
\hline Austria & 0.87 & 34 & 0.01 & 45 & 0.47 & 43 \\
\hline Belgium & 0.93 & 23 & 0.02 & 36 & 0.49 & 35 \\
\hline Brazil & 0.86 & 38 & 0.03 & 33 & 0.48 & 40 \\
\hline Canada & 0.66 & 50 & 0.17 & 14 & 0.47 & 52 \\
\hline Chile & 0.86 & 37 & 0.02 & 44 & 0.47 & 48 \\
\hline China & 1.00 & 1 & 0.21 & 11 & 0.61 & 5 \\
\hline Hong Kong & 1.00 & 1 & 0.25 & 10 & 0.63 & 4 \\
\hline Colombia & 0.86 & 36 & 0.02 & 42 & 0.47 & 46 \\
\hline
\end{tabular}




\begin{tabular}{|c|c|c|c|c|c|c|}
\hline \multirow[t]{2}{*}{$\begin{array}{c}\text { DMU } \\
\text { (Country) }\end{array}$} & \multicolumn{2}{|c|}{$\begin{array}{c}E_{n}^{m} \text { (Front-Stage } \\
\text { Efficiency) }\end{array}$} & \multicolumn{2}{|c|}{$\begin{array}{c}E_{n}^{a} \text { (Behind-Stage } \\
\text { Efficiency) }\end{array}$} & \multicolumn{2}{|c|}{$E_{n}^{t}$ (Total Efficiency) } \\
\hline & $\begin{array}{c}\text { Evaluation } \\
\text { Index Results }\end{array}$ & Rank & $\begin{array}{c}\text { Evaluation } \\
\text { Index Results }\end{array}$ & Rank & $\begin{array}{c}\text { Evaluation } \\
\text { Index Results }\end{array}$ & Rank \\
\hline Czech Republic & 0.88 & 30 & 0.00 & 55 & 0.47 & 45 \\
\hline Egypt & 0.82 & 47 & 0.01 & 46 & 0.46 & 55 \\
\hline Ethiopia & 1.00 & 1 & 0.02 & 39 & 0.51 & 24 \\
\hline Finland & 1.00 & 1 & 0.02 & 43 & 0.51 & 26 \\
\hline France & 0.48 & 53 & 0.71 & 4 & 0.55 & 14 \\
\hline Germany & 0.58 & 51 & 0.48 & 6 & 0.54 & 16 \\
\hline Greece & 0.83 & 44 & 0.04 & 32 & 0.47 & 47 \\
\hline Hungary & 0.99 & 20 & 0.01 & 53 & 0.50 & 32 \\
\hline Iceland & 1.00 & 1 & 0.16 & 16 & 0.58 & 9 \\
\hline India & 0.90 & 26 & 0.06 & 26 & 0.50 & 29 \\
\hline Indonesia & 0.88 & 33 & 0.05 & 29 & 0.49 & 36 \\
\hline Ireland & 1.00 & 1 & 0.14 & 19 & 0.57 & 10 \\
\hline Israel & 1.00 & 1 & 0.06 & 27 & 0.53 & 17 \\
\hline Italy & 0.83 & 45 & 0.09 & 23 & 0.49 & 34 \\
\hline Japan & 0.45 & 55 & 0.80 & 3 & 0.56 & 12 \\
\hline Jordan & 0.88 & 32 & 0.01 & 50 & 0.47 & 44 \\
\hline Kenya & 0.91 & 24 & 0.01 & 52 & 0.48 & 38 \\
\hline Latvia & 1.00 & 1 & 0.01 & 47 & 0.51 & 28 \\
\hline Lebanon & 1.00 & 1 & 0.04 & 30 & 0.52 & 19 \\
\hline Luxembourg & 1.00 & 1 & 0.09 & 24 & 0.54 & 15 \\
\hline Malaysia & 0.85 & 41 & 0.02 & 40 & 0.47 & 50 \\
\hline Malta & 1.00 & 1 & 0.20 & 12 & 0.60 & 6 \\
\hline Korea & 0.86 & 39 & 0.10 & 22 & 0.51 & 27 \\
\hline Mexico & 0.46 & 54 & 0.26 & 9 & 0.39 & 56 \\
\hline Morocco & 0.84 & 43 & 0.02 & 37 & 0.46 & 53 \\
\hline Netherlands & 0.81 & 48 & 0.15 & 17 & 0.52 & 23 \\
\hline New Zealand & 0.55 & 52 & 0.31 & 7 & 0.46 & 54 \\
\hline Nigeria & 1.00 & 1 & 0.00 & 56 & 0.50 & 31 \\
\hline Panama & 1.00 & 1 & 0.11 & 21 & 0.56 & 13 \\
\hline Peru & 0.87 & 35 & 0.01 & 48 & 0.47 & 51 \\
\hline Philippines & 0.90 & 28 & 0.02 & 38 & 0.48 & 37 \\
\hline Poland & 0.90 & 27 & 0.01 & 49 & 0.48 & 41 \\
\hline Portugal & 0.85 & 42 & 0.02 & 34 & 0.47 & 49 \\
\hline Romania & 0.89 & 29 & 0.00 & 54 & 0.47 & 42 \\
\hline Russia & 0.99 & 21 & 0.04 & 31 & 0.52 & 22 \\
\hline Rwanda & 1.00 & 1 & 0.01 & 51 & 0.50 & 30 \\
\hline Saudi Arabia & 0.97 & 22 & 0.07 & 25 & 0.53 & 18 \\
\hline Singapore & 1.00 & 1 & 0.30 & 8 & 0.65 & 2 \\
\hline South Africa & 1.00 & 1 & 0.02 & 41 & 0.51 & 25 \\
\hline Spain & 0.39 & 56 & 1.00 & 1 & 0.56 & 11 \\
\hline Switzerland & 0.91 & 25 & 0.05 & 28 & 0.50 & 33 \\
\hline Thailand & 0.86 & 40 & 0.12 & 20 & 0.52 & 21 \\
\hline Turkey & 1.00 & 1 & 0.16 & 15 & 0.58 & 8 \\
\hline UAE & 1.00 & 1 & 0.19 & 13 & 0.59 & 7 \\
\hline United Kingdom & 0.68 & 49 & 0.57 & 5 & 0.64 & 3 \\
\hline United States & 1.00 & 1 & 1.00 & 1 & 1.00 & 1 \\
\hline
\end{tabular}


Appendix D. RPM: Efficiency Evaluation Results for the Same Weight

\begin{tabular}{|c|c|c|c|c|c|c|}
\hline \multirow{2}{*}{$\begin{array}{c}\text { DMU } \\
\text { (Country) }\end{array}$} & \multicolumn{4}{|c|}{$\begin{array}{c}\text { Evaluation Results (Scores } \\
E_{n}^{a} \text { (Behind-Stage } \\
\text { Efficiency) }\end{array}$} & \multicolumn{2}{|c|}{$E_{n}^{t}$ (Total Efficiency) } \\
\hline & $\begin{array}{c}\text { Evaluation } \\
\text { Index Results }\end{array}$ & Rank & $\begin{array}{c}\text { Evaluation } \\
\text { Index Results }\end{array}$ & Rank & $\begin{array}{c}\text { Evaluation } \\
\text { Index Results }\end{array}$ & Rank \\
\hline Argentina & 0.88 & 30 & 0.02 & 35 & 0.48 & 39 \\
\hline Australia & 0.82 & 46 & 0.15 & 18 & 0.52 & 20 \\
\hline Austria & 0.87 & 33 & 0.01 & 45 & 0.47 & 43 \\
\hline Belgium & 0.93 & 23 & 0.02 & 36 & 0.49 & 35 \\
\hline Brazil & 0.86 & 39 & 0.03 & 33 & 0.48 & 40 \\
\hline Canada & 0.66 & 50 & 0.17 & 14 & 0.47 & 52 \\
\hline Chile & 0.86 & 36 & 0.02 & 44 & 0.47 & 48 \\
\hline China & 1.00 & 1 & 0.21 & 11 & 0.61 & 5 \\
\hline Hong Kong & 1.00 & 1 & 0.25 & 10 & 0.63 & 4 \\
\hline Colombia & 0.86 & 37 & 0.02 & 42 & 0.47 & 46 \\
\hline Czech Republic & 0.88 & 29 & 0.00 & 55 & 0.47 & 45 \\
\hline Egypt & 0.82 & 47 & 0.01 & 46 & 0.46 & 55 \\
\hline Ethiopia & 1.00 & 1 & 0.02 & 39 & 0.51 & 24 \\
\hline Finland & 1.00 & 1 & 0.02 & 43 & 0.51 & 26 \\
\hline France & 0.48 & 53 & 0.71 & 4 & 0.55 & 14 \\
\hline Germany & 0.58 & 51 & 0.48 & 6 & 0.54 & 16 \\
\hline Greece & 0.83 & 44 & 0.04 & 32 & 0.47 & 47 \\
\hline Hungary & 0.99 & 20 & 0.01 & 53 & 0.50 & 31 \\
\hline Iceland & 1.00 & 1 & 0.16 & 16 & 0.58 & 9 \\
\hline India & 0.88 & 32 & 0.07 & 26 & 0.50 & 32 \\
\hline Indonesia & 0.87 & 34 & 0.05 & 28 & 0.49 & 36 \\
\hline Ireland & 1.00 & 1 & 0.14 & 19 & 0.57 & 10 \\
\hline Israel & 1.00 & 1 & 0.06 & 27 & 0.53 & 17 \\
\hline Italy & 0.83 & 45 & 0.09 & 23 & 0.49 & 34 \\
\hline Japan & 0.45 & 55 & 0.80 & 3 & 0.56 & 12 \\
\hline Jordan & 0.88 & 31 & 0.01 & 50 & 0.47 & 44 \\
\hline Kenya & 0.91 & 24 & 0.01 & 52 & 0.48 & 38 \\
\hline Latvia & 1.00 & 1 & 0.01 & 47 & 0.51 & 28 \\
\hline Lebanon & 1.00 & 1 & 0.04 & 30 & 0.52 & 19 \\
\hline Luxembourg & 1.00 & 1 & 0.09 & 24 & 0.54 & 15 \\
\hline Malaysia & 0.85 & 41 & 0.02 & 40 & 0.47 & 50 \\
\hline Malta & 1.00 & 1 & 0.20 & 12 & 0.60 & 6 \\
\hline Korea & 0.86 & 38 & 0.10 & 22 & 0.51 & 27 \\
\hline Mexico & 0.46 & 54 & 0.26 & 9 & 0.39 & 56 \\
\hline Morocco & 0.84 & 43 & 0.02 & 37 & 0.46 & 53 \\
\hline Netherlands & 0.81 & 48 & 0.15 & 17 & 0.52 & 23 \\
\hline New Zealand & 0.55 & 52 & 0.31 & 7 & 0.46 & 54 \\
\hline Nigeria & 1.00 & 1 & 0.00 & 56 & 0.50 & 30 \\
\hline Panama & 1.00 & 1 & 0.11 & 21 & 0.56 & 13 \\
\hline Peru & 0.87 & 35 & 0.01 & 48 & 0.47 & 51 \\
\hline Philippines & 0.90 & 27 & 0.02 & 38 & 0.48 & 37 \\
\hline Poland & 0.90 & 26 & 0.01 & 49 & 0.48 & 41 \\
\hline Portugal & 0.85 & 42 & 0.02 & 34 & 0.47 & 49 \\
\hline Romania & 0.89 & 28 & 0.00 & 54 & 0.47 & 42 \\
\hline
\end{tabular}




\begin{tabular}{|c|c|c|c|c|c|c|}
\hline \multirow[t]{2}{*}{$\begin{array}{c}\text { DMU } \\
\text { (Country) }\end{array}$} & \multicolumn{2}{|c|}{$\begin{array}{c}E_{n}^{m} \text { (Front-Stage } \\
\text { Efficiency) }\end{array}$} & \multicolumn{2}{|c|}{$\begin{array}{c}E_{n}^{a} \text { (Behind-Stage } \\
\text { Efficiency) }\end{array}$} & \multicolumn{2}{|c|}{$E_{n}^{t}$ (Total Efficiency) } \\
\hline & $\begin{array}{c}\text { Evaluation } \\
\text { Index Results }\end{array}$ & Rank & $\begin{array}{c}\text { Evaluation } \\
\text { Index Results }\end{array}$ & Rank & $\begin{array}{c}\text { Evaluation } \\
\text { Index Results }\end{array}$ & Rank \\
\hline Russia & 0.99 & 21 & 0.04 & 31 & 0.52 & 22 \\
\hline Rwanda & 1.00 & 1 & 0.01 & 51 & 0.50 & 29 \\
\hline Saudi Arabia & 0.97 & 22 & 0.07 & 25 & 0.53 & 18 \\
\hline Singapore & 1.00 & 1 & 0.30 & 8 & 0.65 & 2 \\
\hline South Africa & 1.00 & 1 & 0.02 & 41 & 0.51 & 25 \\
\hline Spain & 0.39 & 56 & 1.00 & 1 & 0.56 & 11 \\
\hline Switzerland & 0.91 & 25 & 0.05 & 29 & 0.50 & 33 \\
\hline Thailand & 0.86 & 40 & 0.12 & 20 & 0.52 & 21 \\
\hline Turkey & 1.00 & 1 & 0.16 & 15 & 0.58 & 8 \\
\hline UAE & 1.00 & 1 & 0.19 & 13 & 0.59 & 7 \\
\hline United Kingdom & 0.68 & 49 & 0.57 & 5 & 0.64 & 3 \\
\hline United States & 1.00 & 1 & 1.00 & 1 & 1.00 & 1 \\
\hline
\end{tabular}

\section{Appendix E. RSM Efficiency Evaluation Results}

\begin{tabular}{|c|c|c|c|c|c|c|}
\hline \multirow{2}{*}{$\begin{array}{c}\text { DMU } \\
\text { (Country) }\end{array}$} & \multicolumn{4}{|c|}{$\begin{array}{c}\text { Evaluation Results (Scores) } \\
E_{n}^{a} \text { (Behind-Stage } \\
\text { Efficiency) }\end{array}$} & \multicolumn{2}{|c|}{$E_{n}^{t}$ (Total Efficiency) } \\
\hline & $\begin{array}{c}\text { Evaluation } \\
\text { Index Results }\end{array}$ & Rank & $\begin{array}{c}\text { Evaluation } \\
\text { Index Results }\end{array}$ & Rank & $\begin{array}{c}\text { Evaluation } \\
\text { Index Results }\end{array}$ & Rank \\
\hline Argentina & 0.29 & 49 & 0.16 & 30 & 0.05 & 37 \\
\hline Australia & 0.48 & 25 & 0.52 & 11 & 0.25 & 9 \\
\hline Austria & 0.35 & 43 & 0.11 & 39 & 0.04 & 42 \\
\hline Belgium & 0.52 & 21 & 0.17 & 29 & 0.09 & 31 \\
\hline Brazil & 0.38 & 41 & 0.16 & 31 & 0.06 & 36 \\
\hline Canada & 0.53 & 20 & 0.34 & 15 & 0.18 & 15 \\
\hline Chile & 0.39 & 36 & 0.09 & 45 & 0.04 & 45 \\
\hline China & 1.00 & 1 & 0.21 & 24 & 0.21 & 11 \\
\hline Hong Kong & 1.00 & 1 & 0.25 & 20 & 0.25 & 8 \\
\hline Colombia & 0.32 & 46 & 0.10 & 43 & 0.03 & 46 \\
\hline Czech Republic & 0.47 & 26 & 0.04 & 54 & 0.02 & 53 \\
\hline Egypt & 0.26 & 55 & 0.10 & 41 & 0.03 & 49 \\
\hline Ethiopia & 0.61 & 16 & 0.07 & 50 & 0.04 & 41 \\
\hline Finland & 0.58 & 17 & 0.08 & 47 & 0.05 & 38 \\
\hline France & 0.48 & 24 & 0.71 & 5 & 0.34 & 5 \\
\hline Germany & 0.58 & 18 & 0.48 & 12 & 0.28 & 7 \\
\hline Greece & 0.42 & 34 & 0.30 & 17 & 0.12 & 25 \\
\hline Hungary & 0.56 & 19 & 0.05 & 52 & 0.03 & 47 \\
\hline Iceland & 1.00 & 1 & 0.16 & 33 & 0.16 & 19 \\
\hline India & 0.43 & 31 & 0.24 & 21 & 0.10 & 29 \\
\hline Indonesia & 0.41 & 35 & 0.22 & 22 & 0.09 & 30 \\
\hline Ireland & 1.00 & 1 & 0.14 & 36 & 0.14 & 23 \\
\hline Israel & 0.63 & 15 & 0.22 & 23 & 0.14 & 24 \\
\hline Italy & 0.27 & 51 & 0.61 & 7 & 0.17 & 18 \\
\hline Japan & 0.45 & 29 & 0.80 & 4 & 0.36 & 4 \\
\hline Jordan & 0.31 & 48 & 0.12 & 37 & 0.04 & 44 \\
\hline Kenya & 0.26 & 54 & 0.10 & 42 & 0.03 & 50 \\
\hline
\end{tabular}




\begin{tabular}{|c|c|c|c|c|c|c|}
\hline \multirow[t]{2}{*}{$\begin{array}{c}\text { DMU } \\
\text { (Country) }\end{array}$} & \multicolumn{2}{|c|}{$\begin{array}{c}E_{n}^{m} \text { (Front-Stage } \\
\text { Efficiency) }\end{array}$} & \multicolumn{2}{|c|}{$\begin{array}{c}E_{n}^{a} \text { (Behind-Stage } \\
\text { Efficiency) }\end{array}$} & \multicolumn{2}{|c|}{$E_{n}^{t}$ (Total Efficiency) } \\
\hline & $\begin{array}{c}\text { Evaluation } \\
\text { Index Results }\end{array}$ & Rank & $\begin{array}{c}\text { Evaluation } \\
\text { Index Results }\end{array}$ & Rank & $\begin{array}{c}\text { Evaluation } \\
\text { Index Results }\end{array}$ & Rank \\
\hline Latvia & 0.45 & 30 & 0.06 & 51 & 0.03 & 51 \\
\hline Lebanon & 0.63 & 14 & 0.18 & 27 & 0.11 & 28 \\
\hline Luxembourg & 0.90 & 8 & 0.10 & 44 & 0.09 & 32 \\
\hline Malaysia & 0.43 & 32 & 0.09 & 46 & 0.04 & 43 \\
\hline Malta & 0.78 & 11 & 0.26 & 19 & 0.20 & 12 \\
\hline Korea & 0.49 & 23 & 0.37 & 14 & 0.18 & 14 \\
\hline Mexico & 0.13 & 56 & 0.90 & 3 & 0.12 & 26 \\
\hline Morocco & 0.47 & 27 & 0.15 & 34 & 0.07 & 35 \\
\hline Netherlands & 0.73 & 12 & 0.21 & 25 & 0.15 & 20 \\
\hline New Zealand & 0.33 & 45 & 0.52 & 10 & 0.17 & 16 \\
\hline Nigeria & 0.32 & 47 & 0.03 & 55 & 0.01 & 55 \\
\hline Panama & 0.88 & 9 & 0.16 & 32 & 0.14 & 22 \\
\hline Peru & 0.39 & 37 & 0.07 & 48 & 0.03 & 48 \\
\hline Philippines & 0.36 & 42 & 0.11 & 40 & 0.04 & 39 \\
\hline Poland & 0.27 & 53 & 0.07 & 49 & 0.02 & 52 \\
\hline Portugal & 0.46 & 28 & 0.18 & 28 & 0.08 & 33 \\
\hline Romania & 0.29 & 50 & 0.04 & 53 & 0.01 & 54 \\
\hline Russia & 0.52 & 22 & 0.14 & 35 & 0.07 & 34 \\
\hline Rwanda & 0.83 & 10 & 0.01 & 56 & 0.01 & 56 \\
\hline Saudi Arabia & 0.39 & 39 & 0.40 & 13 & 0.15 & 21 \\
\hline Singapore & 1.00 & 1 & 0.30 & 18 & 0.30 & 6 \\
\hline South Africa & 0.34 & 44 & 0.12 & 38 & 0.04 & 40 \\
\hline Spain & 0.39 & 38 & 1.00 & 1 & 0.39 & 2 \\
\hline Switzerland & 0.38 & 40 & 0.31 & 16 & 0.12 & 27 \\
\hline Thailand & 0.42 & 33 & 0.56 & 9 & 0.23 & 10 \\
\hline Turkey & 0.27 & 52 & 0.62 & 6 & 0.17 & 17 \\
\hline UAE & 1.00 & 1 & 0.19 & 26 & 0.19 & 13 \\
\hline United Kingdom & 0.68 & 13 & 0.57 & 8 & 0.39 & 3 \\
\hline United States & 1.00 & 1 & 1.00 & 1 & 1.00 & 1 \\
\hline
\end{tabular}

\section{References}

1. Aviation Benefits Beyond Borders; Air Transport Action Group: Geneva, Switzerland, September 2020. Available online: https://aviationbenefits.org/media/167186/abbb2020_full.pdf (accessed on 26 October 2020).

2. Annual Review 2019; IATA: Montreal, QC, Canada, 2019. Available online: https://www.iata.org/en/publicatio ns/annual-review/ (accessed on 26 October 2020).

3. Biosafety for Air Transport: A Roadmap for Restarting Aviation v.3; IATA: Montreal, QC, Canada, 2020. Available online: https://www.iata.org/contentassets/5c8786230ff34e2da406c72a52030e95/roadmap-safely-re starting-aviation.pdf (accessed on 26 October 2020).

4. Humphreys, B.; Morrell, P. The potential impacts of the EU/US Open Sky Agreement: What will happen at Heathrow after spring 2008. J. Air Transp. Manag. 2009, 15, 72-77. [CrossRef]

5. Martín, J.C.; Roman, C. An application of DEA to measure the efficiency of Spanish airports prior to privatization. J. Air Transp. Manag. 2001, 7, 149-157. [CrossRef]

6. Melecký, L.; Staníčková, M. National efficiency evaluation of Visegrad countries in comparison with Austria and Germany by selected DEA models. Proc. 30th Int. Conf. Math. Methods Econ. 2012, 575-580.

7. Barros, C.P.; Dieke, P.U. Performance evaluation of Italian airports: A data envelopment analysis. J. Air Transp. Manag. 2007, 13, 184-191. [CrossRef] 
8. Gillen, D.; Lall, A. Developing measures of airport productivity and performance: An application of data envelopment analysis. Transp. Res. Part E Logist. Transp. Rev. 1997, 33, 261-273. [CrossRef]

9. Good, D.H.; Röller, L.H.; Sickles, R.C. Airline efficiency differences between Europe and the US: Implications for the pace of EC integration and domestic regulation. Eur. J. Oper. Res. 1995, 80, 508-518. [CrossRef]

10. Martín, J.C.; Mendoza, C.; Román, C. A DEA travel-tourism competitiveness index. Soc. Indic. Res. 2017, 130, 937-957. [CrossRef]

11. Merkert, R.; Hensher, D.A. The impact of strategic management and fleet planning on airline efficiency-A random effects Tobit model based on DEA efficiency scores. Transp. Res. Part A Policy Pract. 2011, 45, 686-695. [CrossRef]

12. Porter, M.E. The Competitive Advantage of Nations: With a New Introduction; Free Press: New York, NY, USA, 1990.

13. Smith, A. An Inquiry into the Nature and Causes of the Wealth of Nations; Campbell, R.H., Skinner, A.S., Eds.; Liberty Fund, Inc.: Indianapolis, IN, USA, 1981.

14. Ricardo, D. The Works and Correspondence of David Ricardo; Liberty Fund: Indianapolis, IN, USA, 1951; Volume 11.

15. Cho, D.S. A dynamic approach to international competitiveness: The case of Korea. Asia Pac. Bus. Rev. 1994, 1, 17-36. [CrossRef]

16. Moon, H.C.; Rugman, A.M.; Verbeke, A. A generalized double diamond approach to the global competitiveness of Korea and Singapore. Int. Bus. Rev. 1998, 7, 135-150. [CrossRef]

17. Cho, D.S.; Moon, H.C.; Kim, M.Y. Does one size fit all? A dual double diamond approach to country-specific advantages. Asian Bus. Manag. 2009, 8, 83-102. [CrossRef]

18. Charnes, A.; Cooper, W.W.; Rhodes, E. Measuring the efficiency of decision making units. Eur. J. Oper. Res. 1978, 2, 429-444. [CrossRef]

19. Banker, R.D.; Charnes, A.; Cooper, W.W. Some models for estimating technical and scale inefficiencies in data envelopment analysis. Manag. Sci. 1984, 30, 1078-1092. [CrossRef]

20. Cooper, W.W.; Seiford, L.M.; Tone, K. Data Envelopment Analysis; Springer Nature Switzerland AG: Cham, Switzerland, 2000; pp. 1-40.

21. Aviation Benefits Beyond Borders; Air Transport Action Group: Geneva, Switzerland, October 2018. Available online: https://aviationbenefits.org/media/166711/abbb18_full-report_web.pdf (accessed on 26 October 2020).

22. Chiang, K. Network data envelopment analysis: A review. Eur. J. Oper. Res. 2014, 239, 1-16.

23. ICAO Annual Report 2018. Available online: https://www.icao.int/annual-report-2018/Pages/default.aspx (accessed on 26 October 2020).

24. FAA STRATEGIC PLAN FY 2019-2022; Federal Aviation Administration: Washington, DC, USA, February 2018. Available online: https://www.faa.gov/about/plans_reports/media/FAA_Strategic_Plan_Final_FY2019-2022.pdf (accessed on 26 October 2020).

25. GCAA Strategic Plan 2017-2021; UAE General Civil Aviation Authority: Abu Dhabi, UAE, 2020. Available online: https://www.academia.edu/33034924/GCAA_STRATEGY_PLAN (accessed on 26 October 2020).

Publisher's Note: MDPI stays neutral with regard to jurisdictional claims in published maps and institutional affiliations.

(C) 2020 by the authors. Licensee MDPI, Basel, Switzerland. This article is an open access article distributed under the terms and conditions of the Creative Commons Attribution (CC BY) license (http://creativecommons.org/licenses/by/4.0/). 